JURNAL
FIT(1)PATOLOGI
I N D ON E IA
ISSN: $0215-7950$

KOMUNIKASI SINGKAT

\title{
Spesies Meloidogyne Penyebab Puru Akar pada Seledri di Pacet, Cianjur, Jawa Barat
}

\author{
Species of Meloidogyne as the Primary Cause of Root Knot on Celery \\ in Pacet, Cianjur, West Java
}

Fitrianingrum Kurniawati*, Supramana, Abdul Muin Adnan

Institut Pertanian Bogor, Bogor 16680

\begin{abstract}
ABSTRAK
Nematoda puru akar (NPA) Meloidogyne spp. merupakan parasit utama tanaman seledri (Apium graveolens) yang menimbulkan kerugian. Identifikasi spesies Meloidogyne pada seledri di Indonesia belum pernah dilaporkan. Penelitian ini bertujuan mengidentifikasi spesies Meloidogyne pada seledri secara morfologi. Contoh tanaman seledri yang terinfeksi oleh Meloidogyne spp. diambil dengan metode purposif di Desa Ciputri, Kecamatan Pacet, Kabupaten Cianjur, Provinsi Jawa Barat. Nematoda di dalam jaringan akar dideteksi dengan metode pewarnaan asam fuksin. Identifikasi spesies Meloidogyne dilakukan dengan pengamatan morfologi pola perineal betina. Gejala penyakit puru akar pada seledri ialah daun menguning, kerdil, dan pertumbuhan tanaman di lahan tidak merata. Gejala pada perakaran berupa puru akar berukuran kecil-kecil, jumlahnya banyak dan membentuk untaian seperti rantai. Berbagai stadium perkembangan nematoda, yaitu telur, juvenil, dan nematoda betina berhasil dideteksi melalui pewarnaan pada jaringan akar. Tiga spesies Meloidogyne diidentifikasi sebagai $M$. incognita, $M$. arenaria, dan M. javanica.
\end{abstract}

Kata kunci: identifikasi morfologi, jaringan akar, pewarnaan asam fuksin, pola perineal betina

\begin{abstract}
Root knot nematodes (RKN) Meloidogyne spp. is the primary parasite of celery and reported to cause losses up to $70 \%$. Identification of the Meloidogyne species on celery in Indonesia has not been reported. This study was aimed to identify the species of Meloidogyne on celery based on morphology characters. Samples of Meloidogyne-infected celery plants were taken using purposive sampling method from Ciputri Village, District of Pacet, Cianjur, West Java Province. RKN inside root tissue was detected by acid fuchsin staining method. Meloidogyne species identification was done by morphological observation of female perineal pattern. Disease symptoms found in the field include leaf yellowing, stunted, and uneven growth of celery plants. Roots of infected plants showed the formation of small size root knots, in large numbers and forming strands like a chain. Staining NPA in root tissue was successfully detected various stages of nematode development, i.e. eggs, juveniles and female nematodes. Three Meloidogyne species, namely M. incognita, M. arenaria and M. javanica were identified.
\end{abstract}

Key words: acid fuchsin staining method, female perineal pattern, morphological identification, root tissue

*Alamat penulis korespondensi: Departemen Proteksi Tanaman, Fakultas Pertanian, Institut Pertanian Bogor. Jalan Kamper Kampus IPB Dramaga, 16680

Tel: 0251-8629364,Faks: 0251-8629362,Surel: fitrianingrumk@gmail.com 
Tanaman seledri (Apium graveolens) banyak dibudidayakan di daerah dataran tinggi di Indonesia. Beberapa tahun terakhir ini telah banyak ditemukan penyakit puru akar pada tanaman seledri di beberapa daerah di Indonesia. Rosya dan Winarto (2013) melaporkan nematoda parasit yang berasosiasi dengan tanaman seledri ialah Helicotylenchus, Longidorus, Meloidogyne, Trichodorus, dan Xiphinema.

Gejala penyakit yang banyak terdapat pada akar seledri ialah puru akar yang jumlahnya banyak dan jika dibedah akan terlihat nematoda Meloidogyne betina dengan jumlah banyak. Identifikasi spesies Meloidogyne yang berasosiasi dengan tanaman seledri di Indonesia belum dilaporkan. Penelitian ini bertujuan mengidentifikasi spesies Meloidogyne secara morfologi melalui pola perineal. Survei dilakukan secara acak di beberapa pertanaman seledri di Pasir Sarongge, Desa Ciputri, Kecamatan Pacet, Kabupaten Cianjur Jawa Barat. Lahan pengambilan sampel pada lokasi seluas $1000 \mathrm{~m}^{2}$ berada pada ketinggian $1100 \mathrm{mdpl}$.

Pengambilan sampel dilakukan secara purposif dengan memilih sampel berdasarkan kriteria spesifik gejala penyakit tanaman. Gejala tanaman seledri yang terinfeksi oleh Meloidogyne spp. ialah daun di bagian permukaan atas tanah (tajuk) menguning, tanaman kerdil, pertumbuhan terhambat dan tidak merata (Gambar 1). Pada bagian perakaran tampak gejala puru akar dalam jumlah banyak dengan ukuran kecil,dan membentuk seperti untaian, serta akar berambut banyak (hairy root) (Gambar 2).

Pewarnaan jaringan akar berpuru (Zuckerman et al. 1985) menunjukkan berbagai stadium hidup nematoda. Identifikasi morfologi spesies Meloidogyne spp. berdasarkan pola perineal dilakukan dengan metode Eisenback et al. (1981). Pola perineal nematoda puru akar betina merupakan teknik identifikasi yang umum dilakukan. Beberapa alasan yang mendasari pola perineal digunakan dalam identifikasi morfologi nematoda puru akar, antara lain: pola perineal bersifat stabil dan tidak berubah secara nyata
(Eisenback 1985), nematoda betina ukurannya relatif besar serta mudah ditemukan dalam jaringan yang terinfeksi. Penggunaan mikroskop cahaya dan mikroskop elektron memungkinkan pengamatan terhadap ciri-ciri morfologi nematoda lebih akurat.

Telur Meloidogyne berbentuk oval memanjang (Gambar 3a), juvenil 2 di dalam jaringantanamanberbentukcacing (vermiform) (Gambar 3b). Juvenil 2 berkembang menjadi juvenil 3 dan ukuran tubuh mulai membesar dan mulai terjadi perubahan bentuk nematoda (Gambar 3c). Nematoda betina berbentuk seperti buah pir dengan leher pendek dan bagian posterior membulat, serta menetap di dalam jaringan tanaman (Gambar 3d). Meloidogyne merupakan nematoda endoparasit menetap yang menyebabkan pembengkakan akar karena terjadinya pembesaran dan pembelahan sel-sel korteks dan perisikel (Dropkin 1991).

Berdasarkan pengamatan pada ciri-ciri khusus dari pola perineal nematoda betina, nematoda pada puru akar seledri merupakan $M$. arenaria, M. incognita, dan $M$. javanica. M. javanica memiliki ciri khusus dua garis lateral yang sangat jelas yang memisahkan striae bagian dorsal dengan ventral (Gambar 4a). Pola perineal M. incognita memiliki ciri khas berupa lengkungan dorsal yang tinggi dan menyempit, sedangkan pada bagian luarnya sedikit melebar dan agak mendatar, pola striae-nya terlihat kasar dan bergelombang, serta tidak memiliki garis lateral (Gambar 4b). $M$. arenaria memiliki lengkung dorsal rendah dan ramping di sekitar garis lateral, bagian lengkung striae bercabang menggarpu di dekat garis lateral dengan bagian striae atas lebih mendatar (Gambar 4c).

Jenis tanah di Desa Ciputri ialah andosol yang merupakan jenis tanah dari hasil letusan gunung berapi. Jenis tanah ini memiliki tekstur lempung berpasir yang dapat membantu pergerakan nematoda terutama stadiumjuvenil. Meloidogyne juvenil 2 merupakan stadium yang infektif dan aktif bergerak secara vertikal dan horizontal sejauh $75 \mathrm{~cm}$ dalam waktu sembilan hari pada tanah berpasir (Kurniawan 2010). Suhu optimum untuk pertumbuhan $M$. incognita dan $M$. arenaria antara $15^{\circ} \mathrm{C}$ dan 


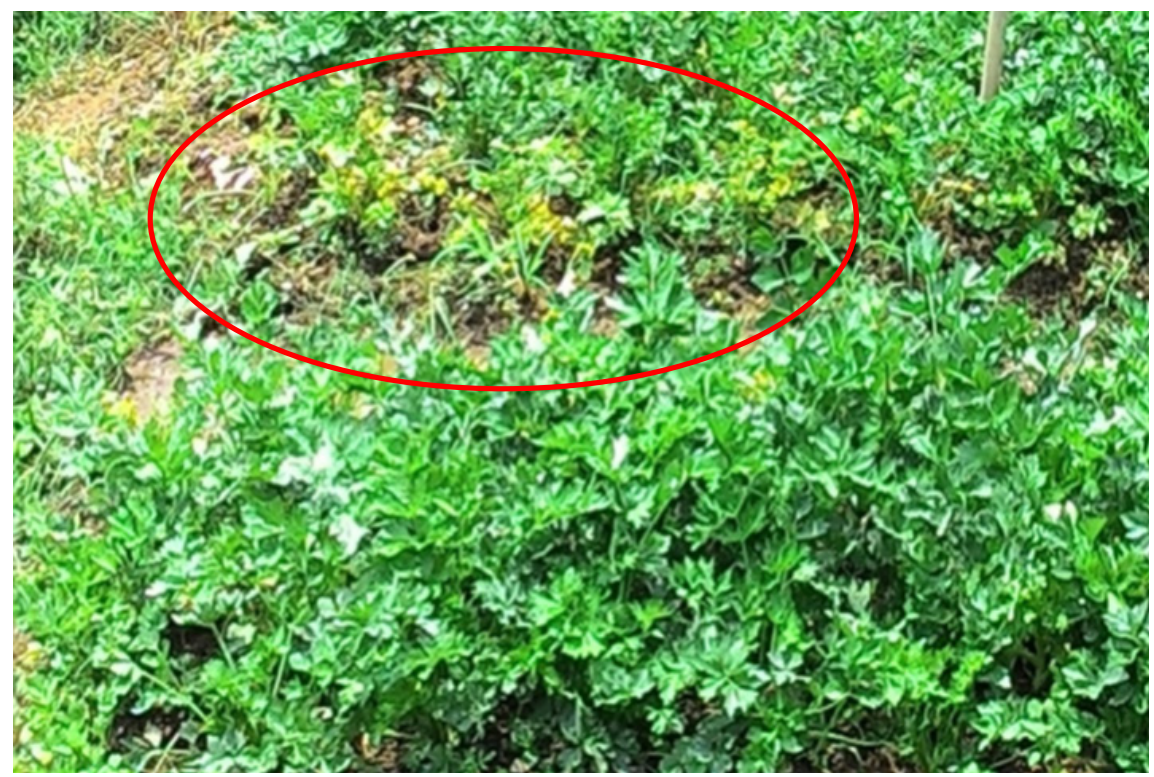

Gambar 1 Gejala tanaman seledri pada tajuk; daun menguning, kerdil, pertumbuhan tidak merata.

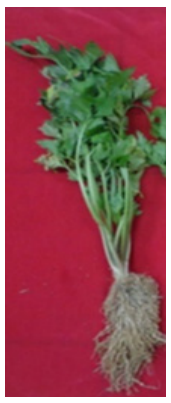

$\mathrm{a}$

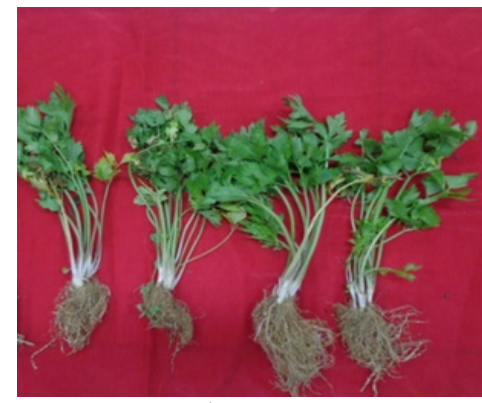

b

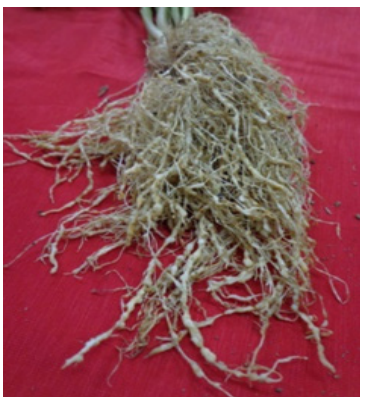

c

Gambar 2 a, Tanaman seledri sehat; b, Tanaman seledri yang terserang Meloidogyne menunjukkan gejala menguningnya daun, kerdil, dan pertumbuhan tanaman tidak merata; c, Gejala puru akar pada perakaran seledri (puru berukuran kecil, berbentuk seperti rantai dan berjumlah banyak).

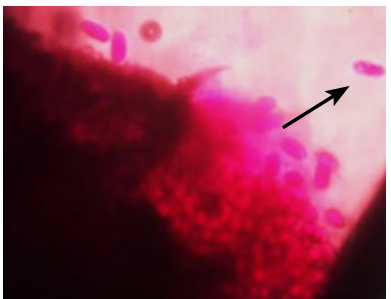

a

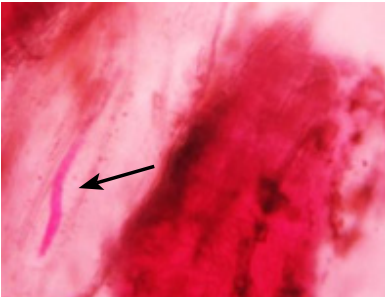

b

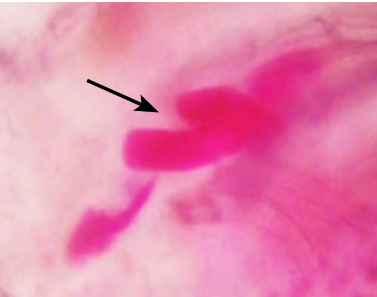

$\mathrm{C}$

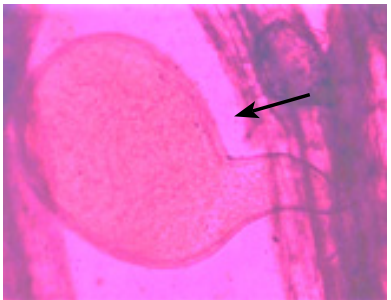

d

Gambar 3 Pewarnaan jaringan akar berpuru. a, Stadium telur; b, Stadium juvenil 2 yang berbentuk seperti cacing (vermiform); c, Stadium juvenil 3 (nematoda mulai berubah bentuk, tubuhnya membengkak); d, Meloidogyne betina berbentuk seperti buah pear, leher pendek, dan bagian posterior membulat.

$25^{\circ} \mathrm{C}$, sedangkan untuk $M$. javanica antara $20{ }^{\circ} \mathrm{C}$ dan $30{ }^{\circ} \mathrm{C}$ (Taylor 1982). Suhu pada siang hari di Desa Pacet berkisar antara $16{ }^{\circ} \mathrm{C}$ dan $20^{\circ} \mathrm{C}$ dan suhu pada malam hari antara
$12{ }^{\circ} \mathrm{C}$ dan $18{ }^{\circ} \mathrm{C}$. Suhu ini sesuai dengan pertumbuhan $M$. arenaria, $M$. incognita, dan M. javanica. 


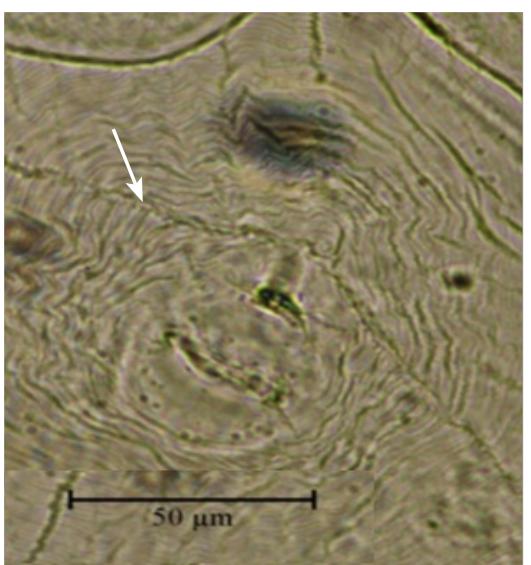

a

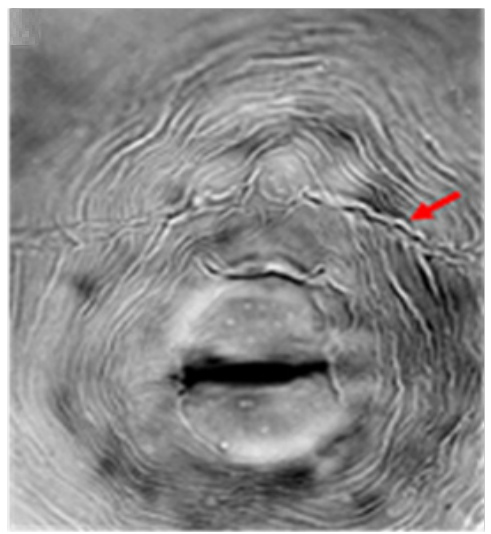

d

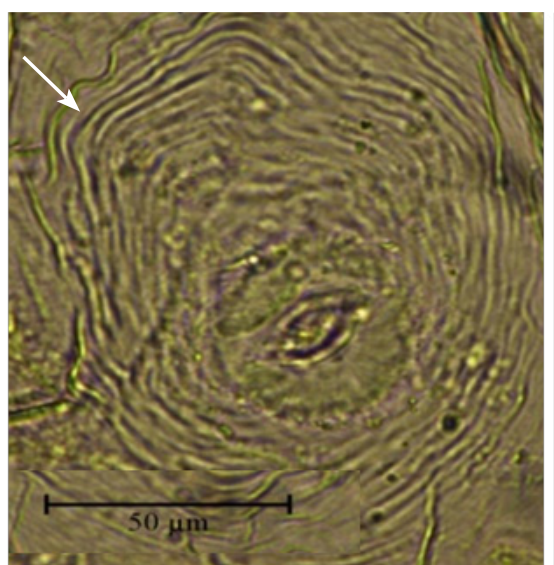

$\mathrm{b}$

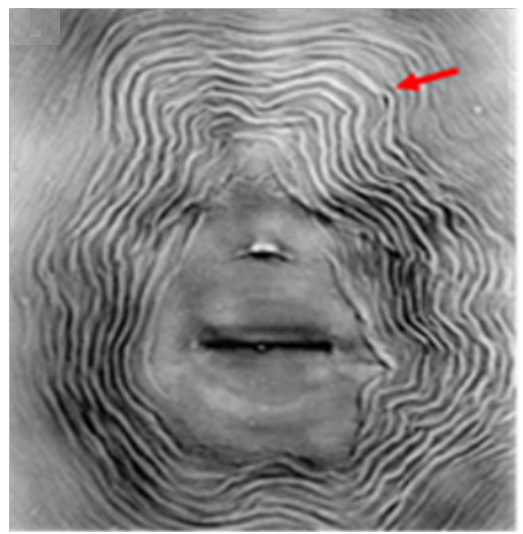

e

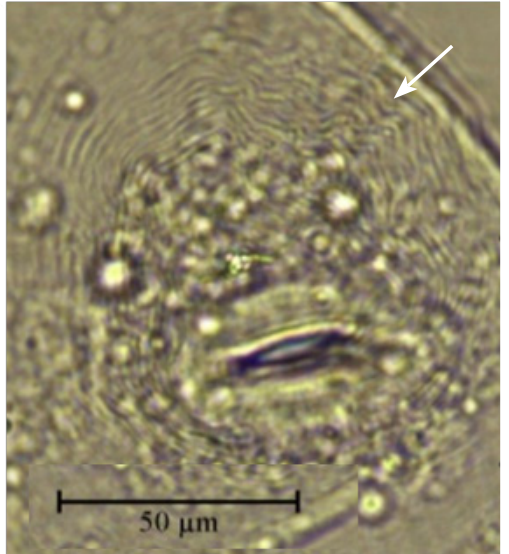

$\mathrm{c}$

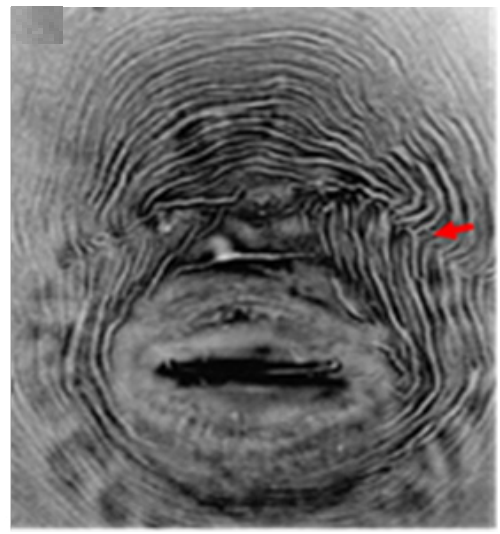

f

Gambar 4 Pola sidik pantat nematoda puru akar yang menginfeksi tanaman seledri. a, Meloidogyne javanica; b, M. incognita; c, M. arenaria . Identifikasi berdasarkan kunci bergambar (Eisenback 1981). d, M. javanica; e, M. incognita; f, M. arenaria

\section{DAFTAR PUSTAKA}

Dropkin VH. 1991. Pengantar Nematologi Tumbuhan. Ed ke-2. Supratoyo, editor. Terjemahan dari: Introduction to Plant Nematology. Yogyakarta (ID): Gadjah Mada University Press.

Eisenback JD, Hirschman H, Sassser JN, Triantaphyllou AC. 1981. A Guide to The Four Most common Species of Root-Knot Nematodes (Meloidogyne species) With a Pictorial Key. Washington DC (US): Cooperative Publication Departement of Plant Pathology and U.S Agency International Development.

Eisenback JD. 1985. Diagnostic characters useful in the identification of four most common species of root-knot nematodes (Meloidogyne spp.) Di dalam: Sasser JN, Carter CC, editor. An advanced treatise on Meloidogyne. Volume I. Biology and Control. Raleigh, NC (US): North Caroline State University Graphics. Hlm 95-112.

Kurniawan W. 2010. Identifikasi penyakit umbi bercabang pada wortel, Daucus carota (L.) Di Indonesia [tesis]. Bogor (ID): Institut Pertanian Bogor.

Rosya A, Winarto. 2013. Keragaman komunitas fitonematoda pada sayuran lahan monokultur dan polikultur di Sumatera Barat. J Fitopatol Indones. 9(3):71-76. DOI: https://doi.org/10.14692/jfi.9.3.71.

Taylor AL, Sasser JN, Nelson LA. 1982. Relationship of Climate and Soil Characteristics to Geographical Distribution of Meloidogyne species in Agricultural Soils. Washington DC (US): North Carolina State University Graphics. 
Zuckerman BM, Mai WF, Harrison MB. 1985.

Plant Nematology, Laboratory Manual. Massachusetts (US): The University of Massachusetts Agricultural Experiment Station Amherst. 